\title{
Listening to the Silence: Huxley, Arnold, and Wells' Scientific Humanity
}

\author{
Jan Vanvelk, KU Leuven, Belgium
}

\begin{abstract}
H. G. Wells' writings from the first few years of the twentieth century inherit a discourse on literature and science that can be traced back to the Victorian debate between Thomas Henry Huxley and Matthew Arnold. The legacy of this dispute that permeates Wells' texts here under investigation lies in the biological metaphors that are deployed to imagine the human as a partaker of humanity in general. The scientific education propagated by Wells crucially engages with the language of the beautiful, the politics of civilisation projects, and the role of fictional and non-fictional texts as devices of social action. Recognising the strong sense in these texts that they could serve as tools for the formation of humanity as the prime agent of science, this article seeks to examine 'humanity' as a term denoting both the audience for and the achievement of the public intellectual's prophetic vision for the future.
\end{abstract}

Keywords: H. G. Wells, Matthew Arnold, Thomas Henry Huxley, science and culture, science fiction, politics, humanity

One of the scenes that left a strong mark on our present-day conception of the relationship between literature and science is the nineteenth-century debate between the Victorian arch-defender of

Victoriographies 5.1 (2015): 72-93

DOI: $10.3366 /$ vic.2015.0184

(C) Edinburgh University Press

www.euppublishing.com/journal/vic 


\section{Huxley, Arnold, and Wells'Scientific Humanity}

culture Matthew Arnold and the relentless propagator of evolutionary theory Thomas Henry Huxley. ${ }^{1}$ Although the duo has often functioned as the embodiment of the clash between the humanities and the natural sciences, scholars have pointed out that both men were trying to reform the same Victorian educational system in light of a changing social configuration and that their efforts to do so cannot simply be understood as reciprocally antagonistic. For instance, Paul White has rightly stressed how the two men were members of 'a community of learned élites' constituted by the idea of a shared 'national culture' of which science and literature could be regarded as just two forms. They were part of a group of reformers, liberal Anglicans, 'bound by ties of friendship, club life, [...] school affiliation, and sometimes by family relation' (116). ${ }^{2}$ After Huxley delivered his famous 'Science and Culture' speech, he received a courteous letter from Matthew Arnold thanking him for the kindness of his address and even lamenting the prospect of 'enter[ing] in controversy with you'. Arnold's concern was, so he said in the letter, to emphasise 'that the dictum about knowing "the best that has been known and said in the world", which was targeted by Huxley as a denial of the role science could play in education, 'was meant to include knowing what has been done in science and art as well as in letters'. ${ }^{3}$ This point is repeated in Arnold's response to Huxley, the Rede Lecture at Cambridge called 'Literature and Science', delivered almost two years after 'Science and Culture'. It suggests that White and others are correct in their estimate that the difference between the two programmes was one of means and not of goals. I will start out by arguing that, indeed, there is a crucial convergence when it comes to the duty of the state educational system to establish a democratic citizenry through acculturation, but this does not mean that Arnold was simply agreeing with Huxley. To document the legacy of the difference that remains, I then turn to H. G. Wells, a writer with a strong allegiance to Huxley's thought who nonetheless, perhaps unwittingly, appeals to the power of the aesthetic in a way that is much more indebted to Arnold than it is to Huxley.

\section{Huxley and Arnold on Science, Literature, and Culture}

In his address in Birmingham, Huxley agreed with Arnold that 'a criticism of life is the essence of culture' but not that literature was sufficient 'for the construction of such a criticism' (9). ${ }^{4}$ If the proponents of classical education claimed to inherit classical culture, this would be under false pretences unless they acknowledged 'that the free deployment of reason, in accordance with scientific method, is the 
sole method of reaching truth' (17). The 'dead civilizations of Greece and Rome' might be limited in their knowledge of the natural world, but their principles are fully compatible with the need for a scientific method in the development of a criticism of life. For a very long time in human history, 'there was no other example of perfect intellectual freedom - of the unhesitating acceptance of reason as the sole guide to truth and the supreme arbiter of conduct' (13). To Huxley, his adversaries among the Humanists who 'favour us with allocutions upon the sadness of the antagonism of science to their mediaeval way of thinking' all too often betray an 'ignorance of the first principles of scientific investigation [...] and an unconsciousness of the weight of established scientific truths, which is almost comical' (16).

The notions of the beginning and the end of the world entertained by our forefathers are no longer credible. It is very certain that the earth is not the chief body in the material universe, and that the world is not subordinated to man's use. It is even more certain that nature is the expression of a definite order with which nothing interferes, and that the chief business of mankind is to learn that order and govern accordingly. [A scientific criticism of life] appeals not to authority, nor to what anybody may have thought or said, but to nature. It admits that all our interpretations of natural fact are more or less imperfect and symbolic, and bids the learner seek for truth not among words but among things. It warns us that the assertion which outstrips evidence is not only a blunder but a crime. (15)

The exacerbation of blunder into crime is significant: it prefigures the ideological implications of Huxley's epistemological regime spelled out in more detail towards the end of his speech, where he advocates that 'both the capitalist and the operative', who in the college at Birmingham would come to 'sojourn together for a while', 'must learn that social phenomena are as much the expression of natural laws as any others; that no social arrangements can be permanent unless they harmonise with the requirements of social statics and dynamics; and that, in the nature of things, there is an arbiter whose decisions execute themselves' (22). This plea for the introduction of 'the teaching of Sociology' stems from the recognition that in the form of government of 'universal suffrage, every man who does his duty must exercise political functions' (23). If 'the steady march of self-restraining freedom' is to be established, 'it will be because men will gradually bring themselves to deal with political, as they now deal with scientific questions'. The scientific approach delivers the promise that it will remedy 'partisan prejudice' and the all too familiar flaws of human 
organisation through the science of sociology, whose prerogative it is to caution that "the machinery of society is at least as delicate as that of a spinning-jenny, and as little likely to be improved by the meddling of those who have not taken the trouble to master the principles of its action'. Wolfgang Lepenies has compellingly demonstrated that the agitated 'struggle' between science and the humanities in the last two centuries in France, Germany, and England often takes shape as a struggle between a scientific approach to social questions (sociology) and literature or literary criticism as the medium of expression felt necessary for these issues. In fact, Lepenies makes the case that Arnold's response to Huxley can only be properly understood by acknowledging that 'Arnold had to defend literature not so much against the natural sciences as against the rising science of sociology' (168) and thus, the biggest threat coming from Darwin's bulldog lay in these final sections of the 'Science and Culture' speech. ${ }^{5}$

Arnold's response in 'Literature and Science' confirms that what is at stake is not the power of natural science but rather its poverty: its inability to properly account for what humans also care about - 'conduct' and 'beauty'. ${ }^{6}$ The real challenge of modern science for culture is the reconfiguration of a new balance between epistemology, ethics, and aesthetics that grants a specifically emotional stability. If knowledge is left to speak for itself as Huxley seemed to propose, then we would find affective equilibrium in, for example, 'Mr. Darwin's famous proposition that "our ancestor was a hairy quadruped furnished with a tail and pointed ears, probably arboreal in its habits"' (64). As it stands, however, the discoveries of modern science are "knowledge not put for us into relation with our sense of conduct, our sense for beauty, and touched with emotion by being so put; not thus put for us, and therefore, to the majority of mankind, after a certain while, unsatisfying, wearying' (65). The feeling of dissatisfaction is experienced by 'the majority of mankind' because it is an instantiation of a fundamental desire 'in men that good should be for ever present to them' and Arnold supposes - though it remains not more than a supposition - that this desire 'acts in us when we feel the impulse for relating our knowledge to our sense of conduct and our sense of beauty' (63):

At any rate, with men in general the instinct exists. Such is human nature. And the instinct, it will be admitted, is innocent, and human nature is preserved by our following the lead of its innocent instincts. Therefore, in seeking to gratify this instinct in question, we are following the instinct of self-preservation in humanity. (63) 
The old perception of nature might have disappeared, 'but the emotions themselves, and their claim to be engaged and satisfied, will remain' (67) and 'it is not on any weak pleadings of my own that I rely for convincing the gainsayers; it is on the constitution of human nature itself, and on the instinct of self-preservation in humanity' (70).

For Huxley, the recognition of the symbolic and its referential limits was the reason for refuting the authority of words in favour of 'things' considered as 'evidence': truth can and must speak for itself because its content equals its expressive and therefore political possibility. For Arnold, to consider truth means separating its denominative from its rhetorical ability. Truth possesses the power to generate truth content but it has to borrow its meaning from a force outside its own prerogative. The force of truth itself is powerful, but nevertheless mediated by ethical and aesthetic considerations that come to light through a bare empirical realisation that 'for us' it is simply not enough. For people like Charles Darwin, so Arnold argued, these concerns might not apply, since he was an example of 'a born naturalist', someone who individually 'has little time or inclination for thinking about getting [natural knowledge] related to the desire in man for conduct, the desire in man for beauty' (65). Here, a disconnect between both men becomes discernible that revolves around the concept of humanity, of 'men in general'. Huxley builds on an initial integration of culture as a theory of life, something that is always already participation and does not require a further rite of passage left to be achieved by an ethical or aesthetic negotiation that answers a demand coming from an emotionally unresponsive public - that is, 'us'. Science is a discourse through which the human species and humanity become virtually interchangeable concepts and culture is just another name for the collectively engaged practice of making sense of the world as human animals just happen to do. Conversely, Arnoldian culture is the expression of an innocent instinct that humanity follows in an attempt at self-preservation. It is at the same time an effect of the fundamental desire "in men that good should be for ever present to them' (63). Humanity therefore involves a preliminary orientation phase that ensures a transition of the good into a presence for humans in general, a presence that, if established, transitions humans into humanity just as it makes intellectual content (say, truth) an individual reality - a reality of feeling that, apathetic Darwins notwithstanding, is characterised by an appeal to 'the constitution of human nature itself' (70). Human nature is not an index for a biological species and its necessary features, but a password to access a reality of common feeling that is immutable as 
much as it is participatory. Although left implicit in Arnold's text, the production of a public is indispensable to the discourse on life which is the province of culture, and in the grasp of this difference between him and Huxley lies the clue for Arnold's recuperation of, to a degree, the most unlikely element in the triad: the beautiful.

So far, we have not mentioned how Arnold attempts to ensure a future for the practice of humane letters if science is insufficient to establish the relationship with conduct and beauty. This responsibility should definitely not be left to the professionals: 'I do not mean that modern philosophical poets and modern philosophical moralists are to come and relate for us, in express terms, the results of modern scientific research to our instinct for conduct, our instinct for beauty' (68). The classics represent the best humane letters available and, to counter Huxley's contention that they are certainly no more or less preferable than, say, modern literature, Arnold asks himself the question: 'have poetry and eloquence the power of calling out the emotions? The appeal is to experience. Experience shows that for the vast majority of men, for mankind in general, they have the power' (67). It is as simple as that. Access to experience is granted by 'the art and poetry and eloquence of men who lived, perhaps, long ago' because 'they have a fortifying, and elevating, and quickening, and suggestive power, capable of wonderfully helping us to relate the results of modern science to our need for conduct, our need for beauty' (68). Arnold has a few words of comfort for the 'poor humanist' who sits at the receiving end of accusations of irrelevance and untimeliness: 'So long as human nature is what it is, their [humane letters'] attractions will remain irresistible' (72) and it should therefore be warranted to entertain 'a happy faith that the nature of things works silently on behalf of the studies which he loves, and that [...] the majority of men will always require humane letters; and so much more, as they have the more and the greater results of science to relate the need in man for conduct, and the need in him for beauty' (72-3). These hopeful words provide for Arnold an occasion to incorporate the language of modern biology into a revaluation effort of humane letters. By inscribing the need for beauty in human nature, the authority of words itself is transformed into the appeal to nature that marked for Huxley the only true way of developing a scientific criticism of life. The principle of observation is not so much overturned as it is reinterpreted as a functional equivalent of the reality of life and nothing else, certainly not a stage on which only truth is allowed to perform in isolated meaningfulness. The refusal to acknowledge that common humanity is in need of the emotional 
effectiveness of poetry and eloquence, is to exile the reality of experience from the province of observation if that observation wants to have anything to say about culture. That is, if culture has a public.

\section{Anticipations}

In 1901, H. G. Wells, who was by then an already reasonably successful author of the science fiction stories he is still remembered for today, started the serialised publication in Fortnightly of a tract that marked the beginning of a new phase in his career. The collection's full title was Anticipations: Of the Reaction of Mechanical and Scientific Progress Upon Human Life and Thought and contained nine pieces, published over the course of as many months, describing the major changes English society was going through and speculating how the civil, economic and moral state of affairs would and should continue to develop in the next one hundred years. Although the endeavour was not Wells' first exposition of a socio-political nature, it was his first sustained, book-length excursion into the matter and it was the one that made him a recognised member of the class of public intellectuals, whose self-appointed task it was to think and rethink social, ethical, and political modernity in industrialised late-Victorian England. ${ }^{7}$ In Wells' oeuvre, this turn to lengthier non-fiction meant first and foremost a retreat from the horrifying evocations of Martians and post-historic crustaceans that featured in his earlier nineteenth-century fantasies of science. Already just after his successful debut in 1895 with The Time Machine and a year later with The Island of Dr Moreau, Wells felt that, certainly, he had struck a responsive chord with the reading public, but his ambitions were not limited to the telling of fancy stories about mad scientists - never mind the fact that he never completely stopped doing it. What he was after was serious literary and intellectual recognition. The former he attempted to achieve right after finishing Moreau, when he started working on his claim to fame as a true respectable novelist, something he distinguished sharply from the early 'scientific romances'. Love and Mr Lewisham was the result of this effort, but as so many of the texts Wells wrote that do not fit the present-day definition of science fiction, it is largely forgotten. ${ }^{8}$ The essays that comprise Anticipations all seek to supply a more down-to-earth version of the future than Wells' fiction in order to highlight the author's desire to speak to his readership about the future in another genre than futuristic narrative. They are based on the principle that if a vision of the future is to be prescient, it must not only deal with what his contemporary peers all recognised as the most pressing questions of 
the time, including the fate of the labouring poor, the future of democracy, and the threat of a war on a wholly different scale than was ever imagined before. It must also find a way to frame these issues as part of a larger direction which would allow hypotheses about the future to be as thoughtful as possible by virtue of extrapolation from confident historical analysis.

The conspectus of turn-of-the-century English society Anticipations thus offers as the basis for speculation, is based on the idea that industrialisation, in Wells' wording the 'development of mechanism' (Anticipations 75), has not only altered the world through the spoils of technological innovation - most notably the ramifications of new systems of transportation - but also through the remodification of labour. ${ }^{9}$ The labouring poor's only asset is the vast supply of unskilled work, pure undirected energy that is now delivered by machinery. These 'People of the Abyss', as they are abrasively called by Wells, will be entirely superfluous in the coming age when a new class of properly educated mechanics will come to dominate the labour force. The education of these men - yes, they are all men - is not limited to their participation in the institutional entity of the school reorganised as a job training programme: '[The educated engineer] must get a grasp of that permanent something that lies behind the changing immediate practice [...] they will have to be educated rather than trained after the fashion of the old craftsman' (95-6). Far more than the demand for more and better training of the work force, the transformation of the mechanical revolution extends to a call for a new consciousness, for a citizenry to gain insight into the underlying currents beneath the blueprint. The distinction between education and training follows the idea that rather than an industrial or political achievement, the break with the past was the result of "that process of vigorous and fearless criticism which is the reality of science, and of which the development of mechanism and all that revolution in physical and social conditions we have been tracing, is merely the vast imposing material byproduct' (311). Hence, the subject of class as it occurs in Wells' tract should not be mistaken for the pursuit of a radical socialism, and not only because of Wells' troubling damnation of the labouring poor. In the new 1914 edition of Anticipations, Wells added a footnote to emphasise that if people tended to interpret his work as heavily engaging with class distinctions (the shift of power from the capitalist to the engineering class), this was certainly not his design: "my intention at least, was to contrast social forces or elements that more often than not will be found in conflict in individual men and individual households, not to contrast classes in the 
community, - much less stratified classes' (Anticipations 1914: 142). Moreover, in the new preface for this edition, Wells, wishing to distance himself even further from some of his readers' presumption that class consciousness would be a central feature of his new republicans, reminded them that 'the New Republic is not a type and a class of persons but a power in men's minds and mankind' (1914: xiii; original emphasis). The rise of the new 'class' is not conditioned by the 'Produktionsweise des materiellen Lebens', a sign of the 'naturwissenschaftlich treu zu konstatierende[] Umwälzung in den ökonomischen Produktionsbedingungen' (Marx iii. 839), but is an 'unorganized power [...] something transcending persons just as physical or biological science or mathematics transcends persons'. ${ }^{10}$ As 'an extension of the spirit of science to all human affairs' (1914: xii), the 'unorganized power' is not a scientific socialism; it is the 'extension' of that spiritual transcendence of the kind that occurs when one observes scientifically. Therefore, the power that will finally supplant even democracy is neither a new regime nor a new class of people in charge - although all of these things might (or might not) occur - but nothing less than 'the power of sanity, the power of the thing that is provably right' (Anticipations 1902: 231).

In this historical narrative of intellectual development, Wells sees a revolutionary advancement emerge in Thomas R. Malthus' Essay on Population. Malthus impressed on the minds of men an unequivocal admonition of 'the fundamental fact that the main mass of the business of human life centres about reproduction' (312); this was deeply at odds with the atavistic naivety of traditional utopians who dreamt up their prospective societies without sufficient recognition of the material urgency of population and food supply. ${ }^{11}$ New thinkers like Darwin and Alfred Russel Wallace realised that the radical insight of Malthus' thought was the rediscovery of the truth 'that all men are individual and unique, and, through long ranges of comparison, superior and inferior upon countless scores' (313-4). The diversity so often denounced by the "liberalizing" movements' (313) of the past century came to be recognised, according to Wells, as the species' most important weapon against extinction. In the wake of modern intellectual illumination, the rethinking of the whole of the ethical scheme, destabilised by truth's material mandate, becomes a pressing but as yet unfinished task, and Anticipations announces itself as a part of this project: 'this present time is essentially the opening phase of a period of ethical reconstruction, a reconstruction of which the new republic will possess the matured result' (311). The reconfiguration 


\section{Huxley, Arnold, and Wells'Scientific Humanity}

is to be done on the grounds of science and truth, starting out from its bare essentials:

Under scientific analysis the essential facts of life are very clearly shown to be two - birth and death [... .] Procreation is the triumph of the living being over death; and in the case of man, who adds mind to his body, it is not only in his child but in the dissemination of his thought, the expression of his mind in things done and made, that his triumph is to be found. And the ethical system of these men of the new republic [...] will be shaped primarily to favor the procreation of what is fine and efficient and beautiful in humanity - beautiful and strong bodies, clear and powerful minds, and a growing body of knowledge - and to check the procreation of base and servile types, of fear-driven and cowardly souls, of all that is mean and ugly and bestial in the souls, bodies, or habits of men. To do the latter is to do the former; the two things are inseparable. (322-3)

The triumph of life is, to use the idiom of a later scientific prophet, man's survival not only as a string of genes but as the materialisation of mind into memes. ${ }^{12}$ The word 'procreation' not only refers to the production of offspring, but far more importantly, it also becomes the principal process of history itself as a testament to the rise and triumph of the scientific spirit. This constitutive confusion of nature and history fuels a language that is easily unmasked as the naturalisation of classic discourses of power pertaining to gender ('men', always with 'strong bodies'), empire ('triumph'), class ('types' as a character-driven name for class), and even race later on in the tract. ${ }^{13}$ For our purposes, it is important to emphasise that these disparaging assaults on degenerative bestiality, the inefficiency of function, and the ugliness of person, are invoked through the aesthetic awareness of the reader and of the new republican. When the procreation of reason and truth enters as a historical movement that favours the beautiful and checks the ugly, it selectively assumes an eye of the beholder that is already infused with a kind of judgement that attempts both to refer to individuality in taste and to a perspicacious unity of assessment within generalised humanity. Beauty acquires the status of an instrument of judgement in the forming of opinion of what exactly will become the subject of the preference of procreation, but it also signals the reliance of the political promise of objectivity on beauty's purity of purpose.

In a mostly dry and barren tract, one can find the occasional passage exerting poetical power for the advocacy of its ideas and it is on such an occasion that we can see how Wells takes a temporary break from sociology to address his readers and assure them of the promise 


\section{Victoriographies}

of the things to come, risking his own metaphors spiralling out of control and revealing the limitations of science in the exertion of politics. In one such passage, modern thought is defined by its ability to distinguish

a spacious scheme of events, opening out - perpetually opening out - with a quality of final purpose as irresistible to most men's minds as it is incomprehensible, opening out with all that inexplicable quality of design that, for example, some great piece of music, some symphony of Beethoven's, conveys. We see future beyond future and past behind past. It has been like the coming of dawn, at first a colorless dawn, clear and spacious, before which the mists whirl and fade, and there opens to our eyes not the narrow passage, the definite end we had imagined, but the rocky, ill-defined path we follow high amid this limitless prospect of space and time. At first the dawn is cold - there is, at times, a quality of terror almost in the cold clearness of the morning twilight - but insensibly its coldness passes, the sky is touched with fire, and presently, up out of the day-spring in the east, the sunlight will be pouring... . And these men of the new republic will be going about in the daylight of things assured. (315-16)

Being severely limited as a human being, the power of the vision of all things passed and all things to come, which grants an insight that is able to start ethics anew, almost overwhelms the modern thinker as he watches over the cold emptiness of deep time. An experience of terror comes over the judging subject when he is granted the privilege of the observer who expands his conception of time and sees 'future beyond future and past behind past'. Betraying a familiarity with the discourse of the sublime, it is exactly the comprehending without overcoming that strengthens the thinker and allows him to develop a philosophy of his world. Or it would be, if only we could listen to Beethoven instead of reading books. The final purpose is 'irresistible' yet 'incomprehensible', moreover; it is 'inexplicable' except for the highly enabling figure of musicality which ensures the aesthetic immediacy of feeling when access to teleological understanding is most severely threatened by the breakdown of rational comprehension. The synaesthesia at the end reinforces the power of an explanation that turns out to be inexplicable. 'At first the dawn is cold [...] but insensibly its coldness passes', and what seemed horrible in a first instance becomes clear and bright but not without the risk of paradox and dissolution. Thus strengthened and assured, the men of the new republic will be ready for the task that is set before them, but only if they feel the coldness pass without sensing it. The empirical sensation that inspires science will only go so far; it is beauty and its direct access 
to emotional response which provides the guarantee that the members of the new class will be able to distinguish who or what is part of the future, as well as offering solace and assurance in the course of its unfolding. Just like Arnold felt the need for the integration of human subjectivity in the generality of humanity by an appeal to human nature, here too, the reader is assured to be a partaker of the promise of the future, even though the particular content of the promise might be very different.

\section{Mankind in the Making}

In the sequel to Anticipations, Mankind in the Making (1903), a further move towards Arnold can be traced. The importance of this work, specifically designed to expand the work started in the prequel, lies in its attempt at conducting the kind of sociology that Huxley found still missing in the new school of science, while strongly relying on the construction of humanity through the metaphors of nature to morph seamlessly into the language of beauty. Mankind in the Making, unlike Anticipations, is strongly preoccupied with the development of the young child as scene and setting for its general conceptions about the condition of humans in society. This archetypal becoming of manin-the-making is first and foremost characterised by his or her mastery of language, triggering the mythical self-origination of the human by the evocation of his or her significant silent other, the animal: 'Other creatures may think, may [...] come almost indefinably near reason [...] but man alone has in speech the apparatus, the possibility, at any rate, of being a reasoning and reasonable creature [... .] With speech humanity begins' (Mankind 121). So not only is the human negatively defined as the non-animal of reason out loud, he or she is also a partaker of his or her own speciesque totality in his or her participation in humanity, or, the other way around, humanity is the natural mark for humankind's species-being. In this setup, speech is preferred over writing, yet Wells' tracts are first and foremost civilisation projects and thus invariably in need of devices of multiplication and dispersal to materially embody their otherwise ethereal message. One of the ways in which the modern state has figured out the formation of its (colonial) subject, touted as a process of becoming human, is the institution of the school. Although Wells' book offers a set of concrete reform proposals for the English educational system, the school has one distinct disadvantage:

We treat the complex, difficult and honourable task of intellectual development as if it were within the capacity of any earnest but 
muddle-headed young lady, or any half-educated gentleman in orders; we take that for granted, and we demand in addition from them the 'formation of character', moral and ethical training and supervision, aesthetic guidance, the implanting of a taste for the Best in literature, for the Best in art, for the finest conduct; we demand the clue to success in commerce and the seeds of a fine passionate patriotism from these necessarily very ordinary persons. (179-80)

The school is paralleled to writing in formative ability: 'It is a new element correlated with the establishment of a wider political order and with the use of written speech' and, as such, not possessed by 'the savage and the barbarian' (178). In a reiteration of the animalistic performance of inability to speak reason, the school triggers the singular thrust of the individual's integration into a political subject, yet if these 'necessarily very ordinary persons' have to carry the new republican's burden then muddle-headedness prevails after all. But there is still hope. Just read books: 'there exists a considerable amount of well-written literature, true stories and fiction, in which, without any clumsy insistence upon moral points, fine actions are displayed in their elementary fineness, and baseness is seen to be base [...] Practically these things are as good as example - they are example' (184).

In 'A Speech at Eton', Arnold also responded to the lack of significance that might be the result of bad schooling, saying that classical literature, 'the best, in literature, has the quality of being in itself formative,-silently formative; of bringing out its own significance as we read it' ('Eton' 22). ${ }^{14}$ Being told, taught, what 'the development and sense of the world' is that the classic masterpiece offers, is not anywhere near the experience of reading it and allowing the work to self-construct its meaningfulness, so that we can 'conceive it as a whole of which we can trace the sequence, and the sense, and the connection with ourselves' (23). Wells does not see the classics as the self-engendered, civilising promise of education due to their lack of resonance for ordinary people 'who know little of history, little of our language, whose only habitual reading is the newspaper, the popular novel, and the sixpenny magazine' (Mankind 373). And so 'the study of works written in the language of a different period, crowded with obsolete allusions, and saturated with obsolete ideas and extinct ways of thinking, is pretentious and unprofitable [...] fruitless and absurd' (373). Modern literature, in contrast, should be actively promoted and nurtured by state institutions: 'the business of contemporary criticism, the encouragement and support of contemporary writers, is just as vitally important in the modern state as the organization of Colleges and Schools' (342; original emphasis). It is 


\section{Huxley, Arnold, and Wells' Scientific Humanity}

more than tempting to notice how a substitution of classic masterpieces with modern literary narratives renders Arnold's project into a blueprint for Wells' investment in the power of literature to circumvent practicality in order to deliver in practice. When the poetry and eloquence of the classics as a relay device is removed from the Arnoldian promise of literature, Wells' call for literature to create harmony between human concerns mirrors that of Huxley's opponent:

Once this deliberate organization of a central ganglion of interpretation and presentation began, the development of the brain and nervous system in the social body would proceed apace. [...] The general innervation of society with books and book distributing agencies would be followed by the linking up of the now almost isolated mental worlds of science, art, and political and social activity in a system of intercommunication and sympathy... . (388)

Through the institution of literature, humans can come together and humanity is formed, but only if cast in biotropes of society qua organism. The practical possibility of redemption can only be processed by biological metaphors that evoke a certain inevitability of time, of the future as the growth of an organism, as something we are all a part of because we are, it just so happens, living. The mechanical circulation of books is full-blown organic behaviour; the artifice of the facilitator is both a sign of this behaviour as procreation promise for ideas and a necessary condition for it. We are organisms no matter what we might think of it, it is our 'incurable reality' (74); but ' $[\mathrm{t}] \mathrm{o}$ rebel against instinct, to rebel against limitation, to evade, to trip up, and at last to close with and grapple and conquer the forces that dominate him, is the fundamental being of man' (78-9). Fighting our own naturalness is the natural essence of the human animal, the animal that circulates his speech through writing. Moreover, the harmony of the mental worlds reveals Wells' awareness of the rhetoric of naturalised inevitability - the not to be resisted desire for conduct, for beauty, in harmony with truth. Arnold just did not comprehend the power of modern technology.

\section{First Men in the Moon}

The First Men in the Moon is a story about a bankrupt playwright (the narrator Bedford) who meets a hermit scientist (Cavor) investigating the possibility of anti-gravity matter. Having discovered this substance called Cavorite, they make their journey to the moon in a glass sphere and discover it to be a barren place at night, but by day, full of life, including mooncows and indeed, moon-men, or Selenites. When they 


\section{Victoriographies}

eat the moon vegetation, they get intoxicated which results in their capture by the moon people, who then take them into the moon itself, a place composed of giant halls and intricate machinery. Through a misunderstanding, Bedford attacks the Selenites and together with Cavor, they fight their way back to the surface, which goes surprisingly well because of their superior physical strength. Not knowing where their sphere is located, they split up, but when Bedford finds it he discovers a note tainted with blood, hastily written by Cavor explaining how he was discovered and is about to get captured or, as Bedford fears, killed. Bedford returns to earth alone and through an accident loses his sphere and thus any ability to return to find out what happened to Cavor. A few months after the adventure, an operative of a Marconi transmitting device picks up a signal from Cavor who is apparently treated well and living with the Selenites. Cavor sends messages to earth about what he learns from Selenite society, including his report about a meeting with the Grand Lunar, a monstrous superbrain, eager to learn more about humans on earth. However, once the Grand Lunar learns from Cavor how and why humans fight wars with guns, a devastating prospect compared to the weaponry of the Selenites, the transmissions get filtered. When Cavor, possibly realising his naivety in being honest to the Grand Lunar, ventures to explain the secret of making Cavorite, the broadcast is cut short entirely, leaving it impossible for anyone to replicate the journey because the secret of Cavorite was lost in the ether.

At first glance, Wells' story is a simple play with perspectives. When the highly rational Selenites discover the true cruelty of mankind, they sever all bonds, even though they are impressed with the ingenuity of man being able to invent Cavorite, which, considering the overall technological superiority of the Selenites, is no small feat. They express a desire to learn from humans, but the interplanetary encounter of knowledge is prematurely shut down by the prospect of a devastating War of the Worlds, featuring many of the imperialist concerns that Wells had already addressed in the 1898 story of that name. That being said, there is something weird going on in The First Men in the Moon and it is not just the mooncows. The book consists of two parts. The first contains the bulk of the narrative: the incredible journey to the moon, the adventures that transpire there, and the return of Bedford without any way of getting back to the moon. It ends like a proper, neat little science fiction story: 'So the story closes as finally and completely as a dream [...] I do more than half believe [sometimes] that the whole thing was a dream...' (First Men 170). In the second part, Bedford returns to his story which he thought was 
finished. The transmissions from Cavor are unexpectedly picked up by 'a Dutch electrician' working with state-of-the-art communication technology 'akin to the apparatus used by Mr Tesla in America' (171). ${ }^{15}$ David Lake points out that Wells in the manuscript first wanted to give a detailed account of Selenite society with Bedford and Cavor both present, but refrained from doing so and just let Bedford return alone without learning anything more about the moon inside. 'But then, probably late in 1900, Wells had his inspiration for Part II: to salvage the deeper view of the moon via radio. He wrote [Part II and] sent this extra part to the monthly magazines, and the story continued in them with no hiatus' (xxii). And so in the story, just like Wells himself, Bedford, even after he 'had seen the greater portion of it appear in The Strand Magazine' (171), revisits his account to share with his readers Cavor's account of Selenite society, promising that eventually, a full 'scientific report' (182) of the transmissions will be published. ${ }^{16}$ Cavor's words overcome the physical limitations that bind humans to the earth to allow us a glimpse of the sub-lunar world in a way that initially did not fit a gothic adventure story, figuring the communicative leap necessary to sociological imagination as scientific practice. Through a revolutionary new instrument of observation, the readers of the science fiction story get to learn about moon society and how they themselves as humans, when subjected to an identical act of observational scrutiny, turn out to be the alien agents of imperial violence and destruction that the reader encountered in The War of the Worlds.

In line with this reading of First Men, Aaron Worth notices how the fading out of the messages from the moon denotes the metaphorical overextension of cultural imperialism, noting that 'technologies of communication are central to the construction of an imperial chronotope linking colonial expansion with cultural fragility' (Worth 77). Wells' elated embrace in Anticipations and other non-fiction work of 'technologically saturated utopias premised upon the eradication of all difference' (85) has to reconcile itself, so argues Worth, with his own scepticism regarding colonial projects, resulting in a text like First Men, where 'Englishness (with language serving as a cultural or racial stand-in) has overextended itself, and flies broadcast, scattered and distorted, across infinite space, destroying itself in the process' (81). Wells, 'by seeking a technological solution to an ideological problem' (85), leaves his chronotopology to express contradiction and indecision without actually openly engaging with these 'ideological fissures' (86) between (global) humanity construction and mono-acculturation. Indeed, in Mankind, one 
encounters exactly the kind of imperial project First Men can just as equally serve as a warning for. To counter the colonial worry of the bastard forms of proper pronunciation in 'white-nigger English' (Mankind 134), Mankind invests technologies such as the "phonograph and telephone' with the possibility of 'storing, analysing, transmitting, and referring to sounds' to guarantee 'a good and beautiful pronunciation of English uniform throughout the world' (137). Down the slippery slope of the power of truth, we can see its convenient absence from pronunciation's evaluation as a distortion that barely gets repressed by the limits of objective judgment. No 'true' English is available to Wells, yet the appeal of the techno-fantastic unification of all is too strong not to implicate the rhetoric of universality as a consequence of truth within the statement. Even though Worth's arguments are hitting the mark when it comes to this central ambiguity within Wells' project, I wish to examine just a little further the way in which a text like First Men to a certain extent is already aware of this and seeks to negotiate itself beyond this contradiction.

In a final dramatic scene that closes the story, Bedford supplies his readers with the last message of Cavor to earth coming to us 'like a cry in the night that is followed by a stillness':

'I was mad to let the Grand Lunar know -'

There was an interval of perhaps a minute. One imagines some interruption from without. A departure from the instrument - a dreadful hesitation among the looming masses of apparatus in that dim, blue-lit cavern - a sudden rush back to it, full of resolve that came too late. Then, as if it were hastily transmitted, came: 'Cavorite made as follows: take -'

There followed one word, a quite unmeaning word as it stands: 'uless'. And that is all.

It may be he made a hasty attempt to spell 'useless' when his fate was close upon him [... .] I see, almost as plainly as though I had seen it in actual fact, a blue-lit shadowy dishevelled Cavor struggling in the grip of these insect Selenites, struggling ever more desperately [...] perhaps even at last fighting and being forced backward step by step out of all speech or sign of his fellows, for evermore into the Unknown - into the dark, into that silence that has no end... . (212-13)

The scientist's voice conveying a sociological discourse and critique is shut out of circulation by a force all too human because it is inspired by an instinct of self-preservation, and, at the same time, radically alien in its inability to maintain communication even when it employs the 
universal discourse of objective truth. With the fate of the secret of Cavorite, which allowed the imagination to leap into space only to find a confrontation with humanity's own cruelty on earth, First Men puts on display the fear not only of the impossibility of interspecific contact unharmed by imperialism, but of its own ineptitude as cautionary tale. The text marks its own uselessness by an 'unmeaning word', 'uless' - an anticipatory echo that Mankind's promise of the interconnectedness of all, might be without you, the addressee, the reader. You-less. Cavorite figures as the performance of the warning itself, equating the uselessness of science with the uselessness of fiction. To not take heed of the message is to expel its content out of the realm of humanity, 'out of all speech or sign of [Cavor's] fellows' disappearing like 'a cry in the night', 'into the dark, into that silence that has no end'. This stark ending does not, however, fully foreclose the civilising project. The undelivered message collapses into an observable silence, a surface noise coming from the apparatus itself that allows raw technology to enunciate the warning of what happens when the artist is not able to relay the scientist's knowledge by an inability of humanity to overcome nature and to rise above it, or, what happens if the forces of prejudice and fear (even if justified) prevail over the desire to advance knowledge and truth in alien exchange. Humanity itself, including its imperial determination, is not forced to face its own alien face of violence and control; it just needs to learn from the example that is First Men, itself the technological instrument of fiction.

Yet, while humanity listens to the dark ether of outer space, a possibility offered by revolutionary communication technology of Marconi-devices and widely distributed science fiction books, its existence itself as a (to be) cautioned observer remains dependent on the text it so desperately needs for establishing an alternative political reality. The last few words at the very end of the story, 'into that silence that has no end', did not appear as such in the American serialisation in Cosmopolitan. There it says: 'into the dark, into a living death' (229). ${ }^{17}$ Life in its cultural and biological sense, harmoniously interwoven in Huxley's discourse as shown above, is enunciated and redacted in a paradox of the living dead - zombie-being as a condition of unreceptivity yet bare existence. Whereas the Strand version refuses to let go of humanity as the proper receptacle for its warning, in Cosmopolitan, the fate of the message itself is not that of it being unheard, but it disappearing into an entity that is not even really living - 'into a living death'. Even though humans might still live and breathe, the failure of science to rescue humanity from war and 
devastation is equalled to the impossibility of participation itself, an exile to the life that is not bio-tropologically living because the rise of humans into humanity is unavailable. Science is prevented from speaking and transmuting its content without a consideration for the good, without a consideration for the ramifications of humans going to the moon. As such, the loss of the scientific message is just as much a salvation of Selenites and humans, as it is the collapse of the latter into a living death because nobody is listening. The breakdown of communication and even of humanity itself is not an imperial overextension, it is a blessing, but one that is achieved by an investment into the tension of narrative, the dramatic ending of a science fiction story in which one of its protagonists is literally forced out of the written text just as it ends.

The Cosmopolitan text foregrounds a crisis of deliverance, not only in terms of editorial materiality - what copy-text is the real, proper warning? - but also by its exclusion of life as a reading life, a life of receptivity the Strand Magazine text and later versions wish to retain. In the silence, voices can be distinguished if they are (at all) used, not so if their audience turns out to be the walking dead, humans without humanity. First Men, aside from trying to think the different, contradictory thoughts of globalised humanity, is a text about textuality itself in the sense that its haunting awareness of public resonance as precondition for and result of its own message highlights as much the limits of science as the limits of literature in the face of indifference. Worth's analysis is pertinent, but we have to consider also that First Men offers an ideological solution to a technological problem: the text's technological inability to be a unifying communication device is transformed into an ideology of warning that constructs humanity and all its ramifications as the only possible audience to avert the danger it forewarns. The Cosmopolitan ending exposes this tactic by offering salvation without humanity that then later had to be replaced by endless silence in an attempt to ward off this consequence by establishing the independent observer's experience of background noise as its silent alternative. Wells, throughout the remaining 40 years of his career, would try to fight for a political humanity of the future as the utopian constitution of an entity that would be able to communicate with alien civilisations on the moon, but in this text, the repressed counter to that project shows the awkward countenance of a thinking that relies so strongly on its own technological circulation that the instability of the text as a single document becomes hard to bear if, as a proper example, it needs a stable carrier for its message. 


\section{Huxley, Arnold, and Wells'Scientific Humanity}

\section{Notes}

Research funding for this article was provided by the Research Foundation - Flanders (FWO). I wish to thank the members of the XXL19 research group at KU Leuven for their helpful suggestions and comments on an earlier draft of this paper.

1. For a historical and bibliographical entry point into the debate, see Roos.

2. As White mentions, this last requirement was met in the case of Huxley and Arnold. Julia, Arnold's niece, married Huxley's eldest son, Leonard.

3. Matthew Arnold to Thomas Henry Huxley, 17 October 1880. Emphasis in the original. Taken from the digital edition of The Letters of Matthew Arnold by the University of Virginia Press: http://rotunda.upress.virginia.edu/arnold/ display.xqy?letter=V5P116D2

4. The speech was delivered at the opening of the Josiah Mason College in Birmingham on 1 October 1880.

5. For a more detailed treatment of Arnold's view on modern literature, see de Graef.

6. Arnold's Rede Lecture at Cambridge, 'Literature and Science', was first delivered on 14 June 1882.

7. The publication of Anticipations triggered the interest of Beatrice Webb, who would invite Wells to the Co-Efficients discussion group and later on the Fabian Society. For a brief, recent account of this episode in British socialist circles see Levitas, esp. 531.

8. For a short presentation of some bibliographical material regarding the inception of Lewisham, see Loing.

9. Page numbers in the text refer to the 1902 edition of Anticipations. Only if explicitly mentioned, the 1914 edition is used.

10. Karl Marx's famous phrasing in the Vorwort to Zur Kritik der Politischen Ökonomie.

11. The produce of the earth 'may increase for ever, and be greater than any assignable quantity; yet still the power of population being in every period so much superior, the increase of human species can only be kept down to the level of the means of subsistence by the constant operation of the strong law of necessity acting as a check upon the greater power' (Malthus i. 15).

12. See Richard Dawkins' eleventh Chapter of The Selfish Gene (1976) entitled 'Memes: The New Replicators'.

13. 'And for the rest, those swarms of black, and brown, and dirty-white, and yellow people, who do not come into the new needs of efficiency? Well, the world is a world, not a charitable institution, and I take it they will have to go. The whole tenor and meaning of the world, as I see it, is that they have to go. So far as they fail to develop sane, vigorous, and distinctive personalities for the great world of the future, it is their portion to die out and disappear' (Anticipations 341). Any extensive treatment of a text like Anticipations needs to address passages such as these. It is my failure to bring them to the reader only in this footnote and without proper comment. Some commentators (cf. Vlitos 28) have made provisional attempts to address these controversial moments as breaches of our 'modern conceptions of political acceptability' (Partington 59); either in terms of some misunderstood ironic play from Wells (McLean 141-2) or by trying to emphasise the progressive nature of Wells' political thought when seen against the backdrop of its own historical context (Partington 51-61). I think these attempts are insufficient because they do not fully engage with the ideological investment that utopian projects depend on when they generate their own vilified others.

14. The address was delivered to the Eton Literary Society on 5 April 1879. 


\section{Victoriographies}

15. Nikola Tesla himself was no stranger to the fantasy of global interconnectedness facilitated by technology. I wish to thank Tom Toremans for pointing this out to me.

16. Strand Magazine serialised First Men in Britain; at the same time, it appeared in America in Cosmopolitan (cf. infra). David Lake finds the Cosmopolitan text to be 'the shortest and most "primitive" (First Men xxviii) of the four versions in circulation in 1901, seeing that Wells did not read proofs for Cosmopolitan, but he did so for Strand.

17. The source is here provided by David Lake's Explanatory Notes in First Men. Worth ignores these different versions as he describes (without referring to the Cosmopolitan version) the end of Cavor's messages to earth as 'a radio silence that figures death' (Worth 81).

\section{References}

Arnold, Matthew. 'A Speech at Eton' [1879]. The Complete Prose Works of Matthew Arnold. Ed. R. H. Super. 11 vols, Ann Arbor: University of Michigan Press, 1973. ix. 20-35.

- 'Literature and Science' [1882]. The Complete Prose Works of Matthew Arnold. Ed. R. H. Super. 11 vols, Ann Arbor: University of Michigan Press, 1974. x. 53-73.

. The Letters of Matthew Arnold: A Digital Edition. Ed. Cecil Y. Lang. 6 vols, Charlottesville: The University Press of Virginia, 1996-2001. Web. 1 November 2014. Graef, Ortwin de. 'Grave Livers: On the Modern Element in Wordsworth, Arnold, and Warner'. English Literary History 74.1 (Spring 2007): 145-169.

Huxley, Thomas Henry. 'Science and Culture' [1880]. Science and Culture and Other Essays. London: Macmillan, 1888. 1-23.

Lepenies, Wolfgang. Between Literature and Science: The Rise of Sociology [1985]. Trans. R. J. Hollingdale. Cambridge: Cambridge University Press, 1988.

Levitas, Ruth. 'Back to the Future: Wells, Sociology, Utopia and Method'. The Sociological Review 58.4 (November 2010): 530-47.

Loing, Bernard. 'Love and Mr Lewisham: Foundations and Sources for a First Social Novel'. H. G. Wells: Interdisciplinary Essays. Ed. Steven McLean. Newcastle: Cambridge Scholars Publishing, 2009. 76-83.

Malthus, Thomas Robert. An Essay on the Principle of Population. Ed. Patricia James. 2 vols, Cambridge: Cambridge University Press, 1989.

Marx, Karl. Zur Kritik der Politischen Ökonomie [1859]. Karl Marx: Ökonomischen Schriften. Ed. Hans-Joachim Lieber. 3 vols, Darmstadt: Wissenschaftliche Buchgesellschaft, 1971. iii. 835-1098.

McLean, Steven. The Early Fiction of H. G. Wells: Fantasies of Science. London: Palgrave Macmillan, 2009.

Partington, John. Building Cosmopolis: The Political Thought of H. G. Wells. Aldershot: Ashgate, 2003.

Roos, David A. 'Matthew Arnold and Thomas Henry Huxley: Two Speeches at the Royal Academy, 1881 and 1883'. Modern Philology 74.3 (February 1977): 316-324.

Vlitos, Paul. 'Unseen Battles: H. G. Wells and Autointoxication Theory'. The Wellsian No. 36 (2013): 25-38.

Wells, H. G. The First Men in the Moon [1901]. Ed. David Lake. New York: Oxford University Press, 1995. 


\section{Huxley, Arnold, and Wells' Scientific Humanity}

Anticipations: Of the Reaction of Mechanical and Scientific Progress Upon Human Life and Thought. New York: Harper \& Brothers, 1902.

- Anticipations: Of the Reaction of Mechanical and Scientific Progress Upon Human Life and Thought [1902]. London: Chapman \& Hall, 1914.

- Mankind in the Making. London: Chapman \& Hall, 1903.

White, Paul. 'Ministers of Culture: Arnold, Huxley and Liberal Anglican Reform of Learning'. History of Science 43.2 No. 140 (June 2005): 115-38.

Worth, Aaron. 'Imperial Transmissions: H. G. Wells, 1897-1901'. Victorian Studies 53.1 (Autumn 2010): 67-89. 